高分解能オージェ電子-光電子コインシデンス分光, 電子ーイオンコインシデンス分光兼用装置の開発

垣内 拓大 $* 1 \cdot$ 橋本 章吾*2 $\cdot$ 藤田 斉彦 $* 2$.

間瀬 一彦*3,*4 ·田中 正俊*2 · 奥沢誠*5

\title{
Development of an Apparatus for High-Resolution Auger Photoelectron Coincidence Spectroscopy (APECS) and Electron Ion Coincidence (EICO) Spectroscopy
}

\author{
Takuhiro KAKIUCHI*1, Shogo HASHIMOTO*2, Narihiko FUJITA*2, \\ Kazuhiko MASE*3,*4, Masatoshi TANAKA*2 and Makoto OKUSAWA*5 \\ ${ }^{* 1}$ Department of Chemistry, Faculty of Science, Ehime University, 2-5 Bunkyocho, Matsuyama 790-8577, Japan \\ *2Department of Physics, Faculty of Engineering, Yokohama National University, 79-5 Tokiwadai, \\ Hodogaya-ku, Yokohama 240-8501, Japan \\ *3Institute of Materials Structure Science, KEK, 1-1 Oho, Tsukuba 305-0801, Japan \\ *4PRESTO, Japan Science and Technology Agency, 5 Sanbancho, Chiyoda-ku, Tokyo 102-0075, Japan \\ *5Faculty of Education, Gunma University, 4-2 Aramakimachi, Maebashi 371-8510, Japan
}

(Received August 18, 2008, Accepted October 11, 2008)

\begin{abstract}
We have developed an electron electron ion coincidence (EEICO) apparatus for high-resolution Auger photoelectron coincidence spectroscopy (APECS) and electron ion coincidence (EICO) spectroscopy. It consists of a coaxially symmetric mirror electron energy analyzer (ASMA), a miniature double-pass cylindrical mirror electron energy analyzer (DP-CMA), a miniature time-of-flight ion mass spectrometer (TOF-MS), a magnetic shield, an xyz stage, a tilt-adjustment mechanism, and a conflat flange with an outer diameter of $203 \mathrm{~mm}$. A sample surface was irradiated by synchrotron radiation, and emitted electrons were energy-analyzed and detected by the ASMA and the DP-CMA, while desorbed ions were mass-analyzed and detected by the TOF-MS. The performance of the new EEICO analyzer was evaluated by measuring $\operatorname{Si} 2 p$ photoelectron spectra of clean $\operatorname{Si}(001)-2 \times 1$ and $\operatorname{Si}(111)-7 \times 7$, and by measuring $\mathrm{Si}-L_{23} V V-\mathrm{Si}-2 p$ Auger photoelectron coincidence spectra $\left(\mathrm{Si}-L_{23} V V-\mathrm{Si}-2 p\right.$ APECS $)$ of clean $\mathrm{Si}(001)-2 \times 1$.
\end{abstract}

\section{1. はじめに}

表面に軟 X 線を照射すると, 1) 内殼光電子放出 $\left(10^{-16}\right.$ 秒 $)$, 2)オージェ過程 $\left(10^{-15} \sim 10^{-14}\right.$ 秒 $\left.), 3\right)$ イオン脱離（10-14〜 $10^{-13}$ 秒）という一連のオージェ刺激イオン脱離（Augerstimulated ion desorption, ASID) 現象が起きる. ASID 機 構を詳細に研究するには, オージェ電子と光電子を同時に測 定するオージェ電子-光電子コインシデンス分光法 (Auger photoelectron coincidence spectroscopy, APECS), 光電子 と光イオンを同時に測定する光電子-光イオンコインシデン ス (photoelectron photoion coincidence, PEPICO) 分光法, オージェ電子と光イオンを同時に測定するオージェ電子-光 イオンコインシデンス (Auger-electron photoion coincidence, AEPICO）分光法が最適である1). また, APECS は, オージェ過程の詳細の研究, サイト選択的オージェ電子 スペクトルの測定, 基板上に作製した超薄膜の表面界面局所 価電子状態の研究などにも利用できる. 一方, PEPICO 分 光は，1)表面吸着水素を高感度に検出できる，2)脱離イオ ンが結合していた原子サイトを特定できる，という特色を持

*1 愛媛大学理学部化学科 ( $=790-8577$ 愛媛県松山市文京町 2-5)

$* 2$ 横浜国立大学工学部知能物理工学科（T240-8501 神奈川県横 浜市保土ヶ谷区常盤台79-5)

*3 高エネルギー加速器研究機構物質構造科学研究所 (テ 3050801 茨城県つくば市大穂 $1-1$ )

*4 科学技術振興機構さきがけ（テ102-0075 東京都千代田区三番 町 5)

*5 群馬大学教育学部（干371-8510 群馬県前橋市荒牧町 4-2）
っており 2), AEPICO 分光は種々のオージェ過程とイオン脱 離の相関を解明できるという特長を持つ ${ }^{3)}$.

我々はコインシデンス分光利用研究の一層の発展を図るた め, 1 台で APECS, AEPICO, PEPICO 分光を行なうことが できる新しい電子-電子ーイオンコインシデンス（electron electron ion coincidence, EEICO) 分光装置を開発した4).さ らに今回, 電子エネルギー分解能を改善した新しい EEICO 分光装置を開発して性能を評価したので報告する.

\section{2. 研究の背景}

新しい EEICO 装置の紹介に先立って, コインシデンス分 光の原理, APECS 装置, 電子ーイオンコインシデンス (electron ion coincidence, EICO) 分光装置, EEICO 装置の 開発の歴史を簡単に紹介する.

\section{1 コインシデンス分光の原理}

一般に, 真のコインシデンス（true coincidence）シグナ ル計数率 $T\left[\mathrm{~s}^{-1}\right]$ は

$$
T=R V g_{1} g_{2}
$$

で与えられる5).ここで $R$ は測定している 2 つの粒子が同時 に放出される現象が試料上で起きる単位体積あたりの頻度 $\left[\mathrm{m}^{-3} \cdot \mathrm{s}^{-1}\right], V$ はつの分析器 (分析器 1 , 分析器 2 ) が共 通して探査する体積 $\left[\mathrm{m}^{3}\right]$ (Fig. 1), $g_{1}, g_{2}$ は分析器 1 , 分 析器 2 の実効的な透過率である. 一方, 偶然のコインシデ ンス (chance coincidence) シグナル*6の計数率 $C\left[\mathrm{~s}^{-1}\right]$ は

$$
C=S_{1} S_{2} t
$$

で与えられる5). ここで, $S_{1}, S_{2}$ は分析器 1 , 分析器 2 のシ 


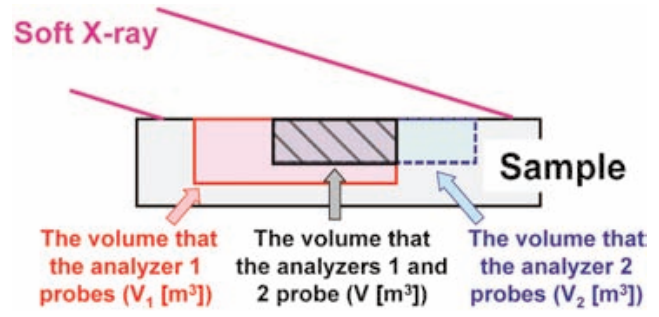

Fig. 1 Schematic diagram of the volume that the analyzers 1 and 2 probe. Particles emitted from $V\left(V=V_{1} \cap V_{2}\right)$ contribute to the true coincidence count rate $(T)$, while those from $\left(V_{1} \cup V_{2}-V\right)$ increases only the chance coincidence count rate $(C)$. The best true-to-chance coincidence ratio $(T / C)$ is achieved when $V=V_{1}=V_{2}$.

グナル計数率 $\left[\mathrm{s}^{-1}\right]$ であり, $t$ は真のコインシデンスシグ ナルが現れる時間幅 $[\mathrm{s}]$ である. $S_{1}, S_{2}$ は

$$
\begin{aligned}
& S_{1}=R_{1} V_{1} g_{1} \\
& S_{2}=R_{2} V_{2} g_{2}
\end{aligned}
$$

で与えられ, $R_{1}\left(R_{2}\right)$ は分析器 1 (分析器 2 ) が測定してい る現象が試料上で起きる単位体積あたりの頻度 $\left[\mathrm{m}^{-3} \cdot \mathrm{s}^{-1}\right]$, $V_{1}\left(V_{2}\right)$ は分析器 1 (分析器 2 ) が探査する体積 $\left[\mathrm{m}^{3}\right]$ であ る (Fig. 1 参照). $V_{1}$ と $V_{2}$ の積集合が $V$ であり $\left(V=V_{1} \cap\right.$ $\left.V_{2}\right), V$ から放出された粒子のみが真のコインシデンスシグ ナル計数率 $T$ に寄与し， $V_{1}$ と $V_{2}$ の和集合から $V$ を除いた 体積 $\left(V_{1} \cup V_{2}-V\right)$ から放出された粒子は偶然のコインシ デンスシグナルの計数率 $C$ のみを増やす.

また，統計的誤差を考慮すると，コインシデンス測定にお いては $T / C$ 比が 1 以上であることが望まれる（Fig. 2 参 照). 励起光源強度を $I$ とすると, (1) 式より $T \propto I, \quad(2)$, (3)式より $C \propto I^{2}$ となる. したがって, コインシデンス分光 に抢いては $I$ の上限值が $T / C \gtrsim 1$ という条件で制限される. このため，Tを大きくするには，

1） $R$ が大きくなる励起条件を選ぶ,

2） $V$ を大きくし， $\left(V_{1} \cup V_{2}-V\right)$ を小さくする $\left(V=V_{1}\right.$ $=V_{2}$ の条件を満たされるとき $T / C$ 比は最大となる $)$,

3） $g_{1}, g_{2}$ を大きく取る,

の 3 点が重要である.

オージェ電子-光電子コインシデンス分光 (APECS) にお いて，Rが大きくなる条件を選ぶには波長可変の放射光源が 適している．また， $V$ を大きくし， $\left(V_{1} \cup V_{2}-V\right)$ を小さく するためには, 2 つの分析器を精度よく位置合わせする必要 がある. 分析器の実効的な透過率 $g$ を大きく取るには, $g$ が 分析器の取达久立体角 $(\Omega)$ に比例することから, 大きな $\Omega$ を持つ分析器を選ぶ必要がある. 光電子分光で最もよく利用 される半球型電子エネルギー分析器 (hemispherical analyzer, HSA）の場合, 標準的な取込久極角 $\alpha=0^{\circ} \sim 5^{\circ}$ で $\Omega=$ $0.024 \mathrm{sr} ，$ レンズ系を改良して $\alpha=0^{\circ} \sim 10^{\circ}$ を実現すると $\Omega=$ $0.095 \mathrm{sr}$ となる. 一方, オージェ電子分光で最もよく使われ ている円筒鏡型電子エネルギー分析器 (cylindrical mirror electron energy analyzer, CMA）では $\alpha=42.3^{\circ} \pm 6^{\circ}$, 方位角

*6 2 つの分析器で検出された粒子が別々の過程で生じたにもかか わらず，真のコインシデンスシグナルの現れる時間領域に偶然 検出される場合, 偶然のコインシデンスシグナルと呼ぶ.

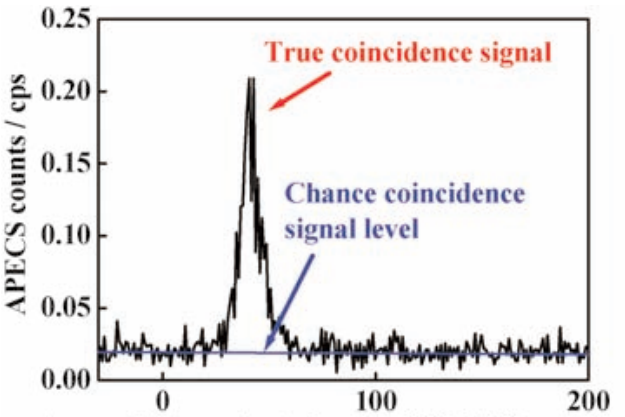

Auger-electron photoelectron TOF difference / ns

Fig. 2 Typical $\mathrm{Si}-L_{23} V V-\mathrm{Si}-2 p$ APECS TOF spectrum of a clean $\mathrm{Si}(111) 7 \times 7$ at $h v=130 \mathrm{eV}$ measured using the previous EEICO analyzer ${ }^{4)}$. The $\mathrm{Si}-2 p$-photoelectron signals with a kinetic energy $(K E)$ of $26.2 \mathrm{eV}$ detected by the CMA were used as trigger signals for the MCS with a dwell time of $1 \mathrm{ns,}$ $\mathrm{Si}-L_{23} V V$-Auger-electron signals with a $K E$ of $88 \mathrm{eV}$ detected by the ASMA were accumulated for $900 \mathrm{~s}$. The Si- $2 p-$ photoelectron counts were $5793 \mathrm{cps}$, while the Si- $L_{23} V V$-Augerelectron counts were $6759 \mathrm{cps}$. The time when the coincidence electrons are emitted from the surface was taken as the zero point of the TOF difference.

の死角が $60^{\circ}$ の場合, $\Omega=0.74 \mathrm{sr}$ である. HSA が 1 次の収束 条件*7しか満たさないのに対し, CMA は $\alpha=42.3^{\circ}$ において 2 次の収束条件*7を満たすことから CMA は分解能と大きな 立体角を両立させるのにも適している. CMA よりさらに大 きな立体角を持ち, 2 次の収束条件を満たす分光器としては 1997年にK. Siegbahn らが報告した同軸対称鏡型電子エネ ルギー分析器 (coaxially symmetric mirror electron energy analyzer, ASMA) がある6).

\subsection{APECS 装置開発の歴史}

最初の表面研究用 APECS 装置は1978年に H. W. Haak らによって開発された。彼らは, $\mathrm{Al} K \alpha_{12}$ 特性 X 線源と 2 個の HSA を用いたAPECS 装置を開発し, 銅 $(\mathrm{Cu})$ の $\mathrm{Cu}$ $2 p_{1 / 2}$ イオン化に由来する $\mathrm{Cu} L_{23} M_{45} M_{45}$ オージェ電子スペ クトル $\left(\mathrm{Cu} L_{23} M_{45} M_{45} \mathrm{AES}\right)$ を測定し, 非常に早い $\mathrm{Cu} L_{2}$ $L_{3} M_{45}$ Coster-Kronig 過程が起きていることを示した7,8). し かし, Haakらの APECS 装置は, コインシデンスシグナル 計数率が $0.03 \sim 0.1$ counts/s (cps) と非常に小さかったため, 1 つのスペクトルを得るのに 1 週間から 1 ヶ月を要した.

1989年, E. Jensen らは, エネルギー可変の放射光と 2 個 の市販のダブルパス CMA を用いた APECS 装置を開発し, $\mathrm{Cu} M_{3} V V$ オージェ電子シグナルをトリガーとして $\mathrm{Cu} 3 p$ 内 殼光電子スペクトル (PES) を測定して, 通常光電子分光法

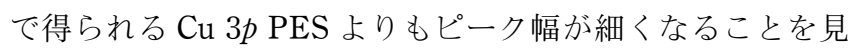
出した9).これは, 通常の $\mathrm{Cu} 3 p \mathrm{PES}$ が全てのオージェ終 状態 $\sum_{i=1}^{n} \varphi_{f}^{i}$ に対応しているのに対し, $\mathrm{Cu}-M_{3} V V-\mathrm{Cu}-3 p$ コイ ンシデンススペクトルはトリガーシグナルの特定オージェ終 状態 $\varphi_{f}^{i}$ に対応した $\mathrm{Cu} 3 p$ 内殼光電子成分のみを測定するた めである. Jensen らは放射光と 2 次の収束条件を満たし立

*7 電子のエネルギーを $E$, 電子の取込み極角を $\alpha$ として $\Delta E$ を $\Delta \alpha$ で展開した場合, $(\Delta \alpha)$ の項まで 0 となる条件を 1 次の収 束条件, $(\Delta \alpha)^{2}$ の項まで 0 となる条件を 2 次の収束条件と呼ぶ. 
体角の大きなダブルパス CMA を利用することでコインシデ ンスシグナル計数率を改善したが, それでも, 一つのコイン シデンススペクトルを得るのに最低でも 2-3 日の積算が必 要であった。

翌1990年 S. Thurgate らは, $\mathrm{Mg} K \alpha$ 特性 X 線源と $127^{\circ}$ 共 軸円筒型分析器 (cylindrical $127^{\circ}$ analyzer) 2 個を用いて, コインシデンスシグナル計数率〜 $0.08 \mathrm{cps}, T / C$ 比 3 の実 験室用 APECS 装置を開発した。これにより，放射光を用い なくても $T / C$ 比のよいコインシデンススペクトルを 1 週間 程度で測定できるようになった ${ }^{10)}$. 彼らは， $3 d$ 金属の電子 スペクトル中に現れるサテライトピークの発生メカニズムを 詳しく議論している. また，2001年には，R. Gotter らが， 放射光と組み合わせた角度分解 APECS が可能な装置を開発 した ${ }^{11)}$ 。この APECS 装置は, 一度に多くの角度分解コイン シデンス測定を実行するために 7 つの HSA を配置している.

飛行時間型電子エネルギー分析器を用いた電子一電子コイ ンシデンス (electron electron coincidence, EECO) 分光装 置も開発されている12,13). 飛行時間型電子エネルギー分析器 はエネルギーが高くなるとエネルギー分解能が低下するため APECS には適さないが, 電子検出効率が非常に高い, 電子 放出角度に関する情報も得られる，という利点がある.

国内でもいくつかの研究グループが APECS 装置の開発に 取組んできた。奥沢らは1994年から実験室内軟 X 線源と 2 個の HSA を組み合わせた APECS 装置の開発に取組んでい るが14-16), まだ真のコインシデンスシグナルを確認するに は到っていない. また, 福島, 吉川らも X 線放射光源と 2 個のHSA を組み合わせたAPECS 装置の開発に取組んだ が17,18), APECS スペクトルを測定するには到っていない. 一方, 間瀬らは, 放射光と同軸対称鏡型電子エネルギー分析 器 (ASMA), シングルパス CMA を同軸同焦点で組み合わ せたAPECS 装置を2004年に開発し, Si (111)の Si- $L_{23} V V-$ Si-2p APECS を測定した ${ }^{1,19)}$. この APECS 分光器は,

1） 2 次の収束条件を満たし, 立体角が大きなASMA $(1.6 \sim 1.2 \mathrm{sr}$ ， エネルギー分解能 $E / \Delta E=80 \sim 130 ）$ を オージェ電子検出用に用いている,

2） 1 次の収束条件を満たし，立体角が大きな CMA $(0.72 \mathrm{sr}$, エネルギー分解能 $E / \Delta E \sim 12)$ を光電子検出 用に用いている,

3） CMA をASMAの内部に同軸同焦点で組み立ててい るため, 2 つの分析器の位置合わせが必要ない,

4） CMA を内蔵したASMAを磁気シールドで覆い, 外 部磁場を遮蔽している,

5） CMA を内蔵した ASMA をXYZ ステージと傾き調整 機構を介して直径 $203 \mathrm{~mm}$ のコンフラットフランジ (ICF203) に一体で組み込んでいるため, APECS 分光 器を放射光が照射されている試料位置に合わせること が極めて容易である,

という特長を持っており， $T / C$ 比〜 10 において $0.86 \mathrm{cps}$ と いう世界最高水準のコインシデンスシグナル計数率を達成し た1,19). その後, CMA をダブルパス化することで CMAの $E / \Delta E$ を〜 20 に，コインシデンスシグナル計数率を $1.67 \mathrm{cps}$ に改善している20).

\section{3 電子-イオンコインシデンス（EICO）分光装置開発 の歴史}

APECS 装置と比較して, 表面研究用電子一イオンコイン シデンス (Electron ion coincidence, EICO) 分光装置開発 例は少ない. 1985 年に, M. L. Knotek と J. W. Rabalais は, 電子銃と CMA, 飛行時間型イオン質量分析器 (Time of flight ion mass spectrometer, TOF-MS）から構成される EICO 分光装置を報告した ${ }^{21)}$. しかしながら， $T / C$ 比が極 めて悪く, 真のコインシデンスシグナルを測定できているか どうかの確証は得られなかった。 1996年, 間瀬らは, 電子 銃と CMA, TOF-MS から構成される EICO 分光装置を開発 して真のコインシデンスシグナルを確認し, AEPICO 分光 法によって $\mathrm{F} / \mathrm{SrTiO}_{3}(100)$ 表面から $\mathrm{F}^{+}$が $\mathrm{F} K V V$ オージェ 過程を経て脱離することを報告した ${ }^{22)}$. EICO 分光装置はそ の後, 放射光と組み合わされ ${ }^{23)}$, 幾度か改良されて電子工 ネルギーの高分解能化，イオン質量分解能の向上，およびコ インシデンスシグナル計数率の向上が図られた ${ }^{24,25)}$. 特に凝 縮 $\mathrm{H}_{2} \mathrm{O}$ の $\mathrm{O} 1 s$ 内殼準位を $4 a_{1}$ 反結合性軌道へ共鳴励起した 場合の共鳴オージェ電子- $\mathrm{H}^{+} \mathrm{AEPICO}$ 測定においては $T / C$ 比〜 50 に㧍いて $T=0.77 \mathrm{cps}$ を達成している3,25). EICO 分 光利用研究の成果は最近の解説記事等に紹介されてい $ろ^{2,3,26)}$.

\section{4 電子-電子-イオンコインシデンス（EEICO）分光装 置開発の歴史}

我々は, APECS 装置と EICO 装置の開発経験を生かして, 2007年に ASMA, シングルパス CMA, TOF-MS から構成 される EEICO 分光装置を開発した ${ }^{4)}$. EEICO 分光装置を用 いれば， 1 台で APECS, PEPICO, AEPICO 分光が可能とな り, 3 種の分光法を組み合わせた研究を効率よく行うことが できる.しかし，CMAの $E / \Delta E か ゙ 〜 20$ 程度と低いことが久 点であった，そこで，今回我々は，CMA をダブルパス化す ることによって, 高分解能 APECS 測定が可能な EEICO 分 光装置を開発した. もちろん本装置は, AEPICO 分光, PEPICO 分光, XPS, AES, イオン脱離実験にも利用でき る.

\section{3. 開 発}

\subsection{EEICO 分光装置}

新しい EEICO 分光装置とAPECS 計測系を Fig. 3 に示 す. EEICO 分光装置は, ASMA およびダブルパス CMA (DP-CMA), TOF-MS, 磁気シールド, XYZ ステージ, 傾 き調整機構, ICF203から構成される. ASMA と DP-CMA, TOF-MS は, 同軸同焦点で設計されていて, TOF-MS は DP-CMA に内蔵され, DP-CMA は ASMA に内蔵されてい る. EEICO 分光器は, 厚さ $0.5 \mathrm{~mm}$, 外径 $140 \mathrm{~mm}$, 全長 150 $\mathrm{mm}$ のパーマロイ-78製磁気シールドで覆われ, 外部磁場か ら遮蔽されている. 試料表面と EEICO 分光器前端板までの 距離は, $2.5 \mathrm{~mm}$ である. EEICO 分光器は超高真空仕様で あり，金属材料としては非磁性の SUS310S 抢よびインコネ ル600, 真空焼鈍して消磁したSUS304 ナベビス, 絶縁材料 としてはアルミナおよびポリイミドチューブを使用している. 


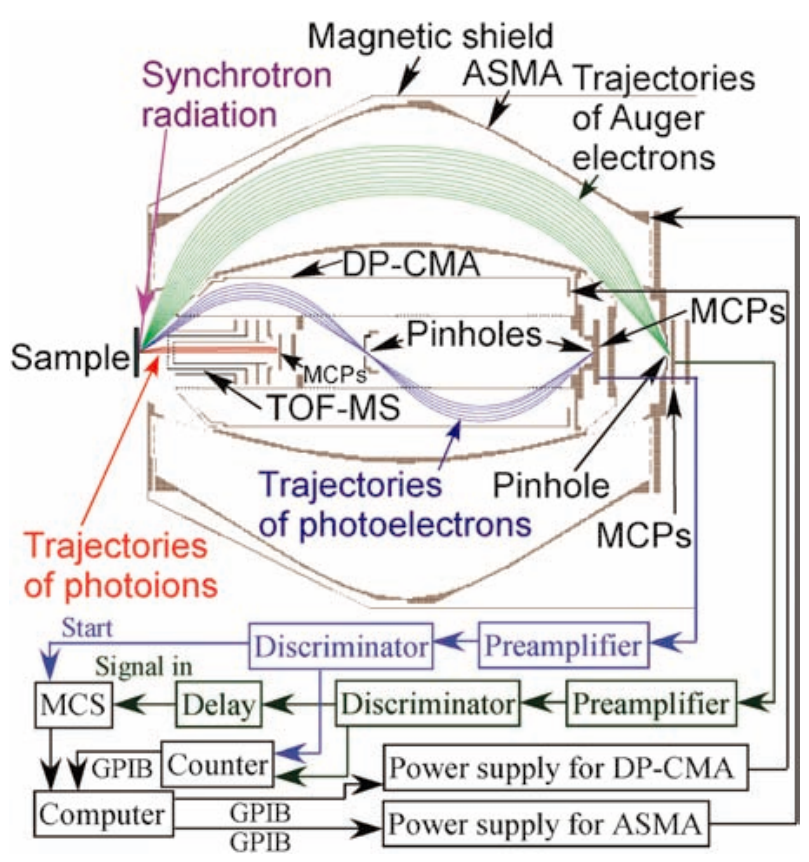

Fig. 3 Schematic diagram of the new EEICO analyzer and the measurement system for APECS. The trajectories of electrons and ions simulated with the SIMION 3D Version 7 are also shown.

\section{2 同軸対称鏡型電子エネルギー分析器 (ASMA)}

ASMA (Fig. 4) は, 外電極 (Fig. 4b), 内電極（Figs. $4 \mathrm{~d}, 4 \mathrm{e}) ， 4$ 枚の補正電極を設置した前（後）端板（Figs. $4 \mathrm{a}$, 4c), ピンホール, およびマイクロチャンネルプレート (MCPs, 浜松ホトニクス, F4655）から構成される. 外電 極および内電極の形状は,

$$
\varphi=a \ln r-a\left(\frac{r^{2}}{2}-z^{2}\right)+d
$$

によって与えられる6).ここで, $\varphi$ は電位, $r$ は中心軸から の距離, $a$ と $d$ は定数, $z$ は, 中心軸方向の距離である. ASMA 外電極の外径は $137.5 \mathrm{~mm}$, 試料表面からピンホール までの距離は $143.5 \mathrm{~mm}$ である. 内電極の開口部にスポット 熔接されたメッシュ (Figs. $4 \mathrm{~d}, 4 \mathrm{e})$ の透過率は $88 \%, \mathrm{MCP}$ 前のピンホールの内径は $1.0 \mathrm{~mm}$, 電子の取込久極角 $(\alpha \pm$ $\Delta \alpha)$ は, $59.5^{\circ} \pm 11.5^{\circ}$ （立体角は $\Omega=1.81 \mathrm{sr}$ ）である. 実効 的な透過率 $g$ は

$$
g=(\Omega / 4 \pi) \cdot\left(T_{\text {mesh }}\right)^{n} \cdot D_{\mathrm{MCP}_{-} \mathrm{e}}
$$

で与えられる.ここで, $T_{\text {mesh }}$ はメッシュの透過率 $\left(T_{\text {mesh }}=\right.$ $0.88), n$ はメッシュの枚数 $(n=2), D_{\mathrm{MCP} \text { e }}$ は MCPsによ る電子の検出効率 $\left.\left(D_{\mathrm{MCP}_{\mathrm{e}} \mathrm{e}}=\sim 0.5\right) 27\right)$ であるので, 本 ASMA では $g=\sim 0.056$ である. ASMA で分光される電子の 運動エネルギー $\left(K E_{\mathrm{ASMA}}\right)$ は, $K E_{\mathrm{ASMA}}=1.83 \times e V_{\mathrm{ASMA}}$ に よって決まる。ここで, $V_{\mathrm{ASMA}}$ は, ASMA 外電極に印加す る電圧である. ASMA は $\alpha \sim 60^{\circ}$ に抢いて 2 次の収束条件を 満たすため, 高分解能と高感度を両立することができる.

\section{3 ダブルパス円筒鏡型電子エネルギー分析器（DP- CMA)}

DP-CMA (Fig. 5) は, 外電極 (Fig. 5b), 内電極 (Fig. 5d), ピンホール，抢よび MCPs（浜松ホトニクス， F4655）

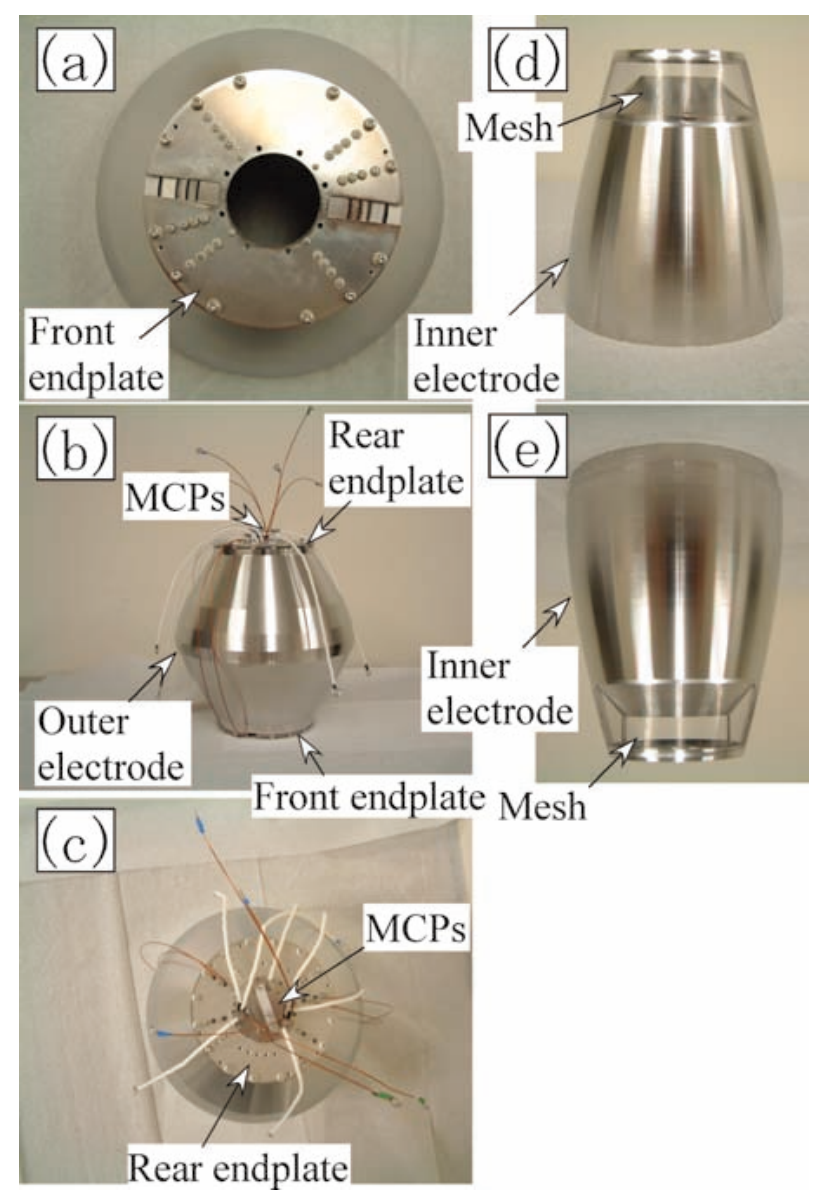

Fig. 4 (a) The front view of the ASMA. (b) The side and (c) back view of the ASMA with a built-in DP-CMA and TOFMS. (d, e) The inner electrodes of ASMA, where the apertures are covered with meshes.

から構成される. DP-CMA 外電極の内径は $40 \mathrm{~mm}$, 内電極 の外径は $20 \mathrm{~mm}$, 試料表面から第 1 段目および 2 段目のピ ンホールまでの距離は順に $61.2 \mathrm{~mm}, 122.8 \mathrm{~mm}$ である.内 電極のアパーチャーに張られたメッシュの透過率は, $84 \%$ である (Fig. 5d). DP-CMAの第1段目拈よび 2 段目の $\mathrm{MCP}$ 前に設置されたピンホールの内径は, 順に $2.0 \mathrm{~mm}$ と $1.5 \mathrm{~mm}, \alpha \pm \Delta \alpha=37.5^{\circ} \pm 4^{\circ}, \Omega=0.43 \mathrm{sr}$ である. 本 DPCMA の実効的な透過率 $g$ は $T_{\text {mesh }}=0.88, n=4, D_{\mathrm{MCP} \_\mathrm{e}}=$

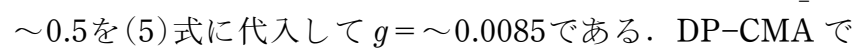
分光される電子の運動エネルギー $\left(E_{\mathrm{DP}-\mathrm{CMA}}\right)$ は, $E_{\mathrm{DP}-\mathrm{CMA}}$ $=1.907 \times e V_{\mathrm{DP}-\mathrm{CMA}}$ によって決まる.ここで, $V_{\mathrm{DP}-\mathrm{CMA}}$ は, $\mathrm{DP}-\mathrm{CMA}$ 外電極に印加する電圧である. CMA は $\alpha=$ $42.3^{\circ}$ において, 2 次の収束条件を満たすが，本装置では $\alpha=$ $37.5^{\circ}$ であるので, 1 次の収束条件しか満たしていない。こ のため, $\Delta \alpha$ を小さくして高分解能化を図っている.

\section{4 ミニチュア飛行時間型イオン質量分析器 (TOF-MS)}

TOF-MS は, 電場シールド, イオン引込久電極, ドリフ トチューブ，抢よび MCPs（浜松ホトニクス， F4655X$\mathrm{D} 10$, 外径 $17 \mathrm{~mm}$, 有効径 $6.5 \mathrm{~mm}$ の特注品）から構成され る (Fig. 6). 試料表面とイオン引込久電極間の距離は 7.5 $\mathrm{mm}$, イオン引込久電極前面とドリフトチューブ前面までの 距離は $1.5 \mathrm{~mm}$, ドリフトチューブの長さは $25.5 \mathrm{~mm}$, イオ 

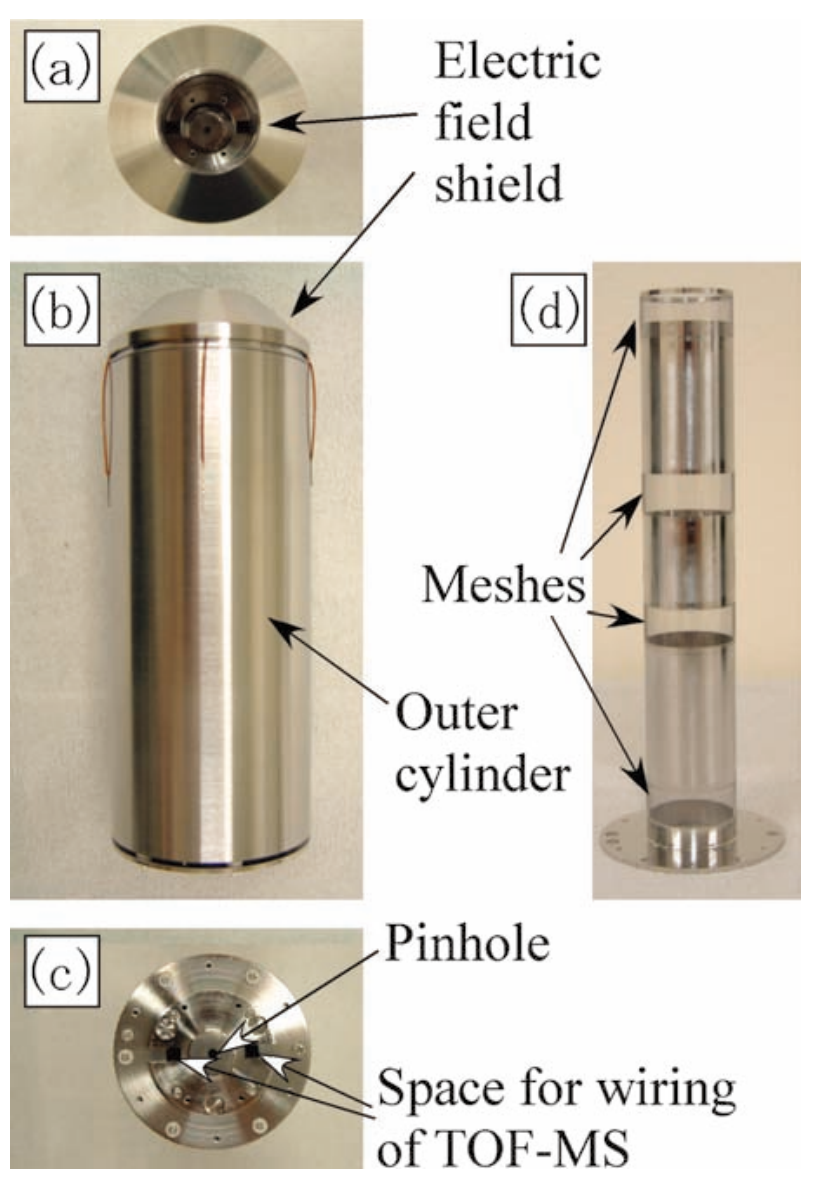

Fig. 5 (a) The front, (b) the side, and (c) the back view of the DP-CMA. (d) Inner electrode with meshes.

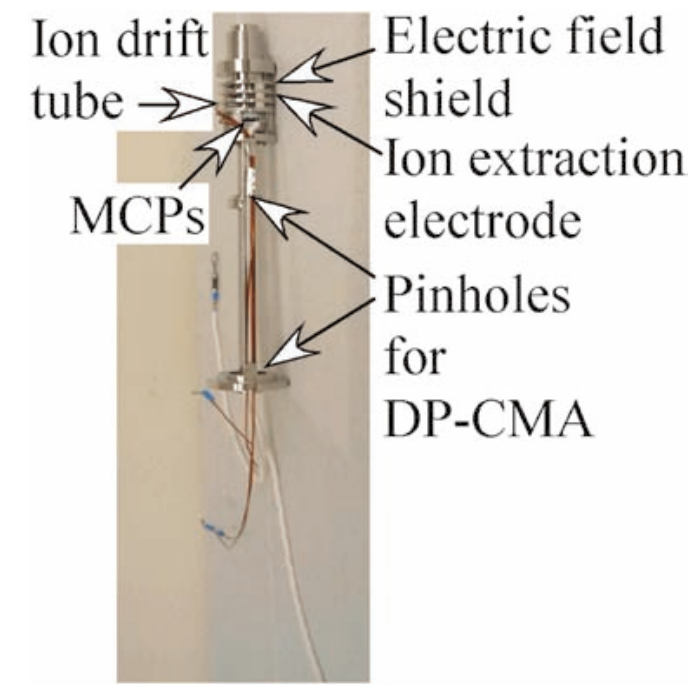

Fig. 6 The side view of the miniature TOF-MS that consists of an electric field shield, an ion extraction electrode, an ion drift tube, and MCPs.

ン引込反電極とドリフトチューブの内径の直径は，それぞれ $8.5 \mathrm{~mm}, 5.5 \mathrm{~mm}$ である. イオン引込反電極とドリフトチ ューブにスポット熔接したメッシュの透過率は，77\%であ る.イオン引込々電極とドリフトチューブに適切な電圧を印 加してすべての脱離イオンを捕集する場合, TOF-MS の実 効的な透過率 $g$ は

$$
g=\left(T_{\text {mesh }}\right)^{n} \cdot D_{\text {MCP_ion }}
$$

ここで, $D_{\mathrm{MCP} \text { ion }}$ MCPsによるイオンの検出効率 $\left.\left(D_{\mathrm{MCP} \_ \text {ion }}=\sim 0.6\right)^{27}\right)$ である. 本 TOF-MS では $T_{\text {mesh }}=0.77$, $n=2$ であるから,$g=\sim 0.35$ である.

\section{5 組立て}

TOF-MS をDP-CMA に内蔵し，DP-CMA をASMS に 内蔵する際，もっとも難しいのは配線処理である。本装置で は配線スペースを 2 箇所設け, DP-CMA とASMA の方位 角に抢ける死角を最小限に抑えつつ, 組立て容易な構造に設 計している (Figs. 4b, 4c, 5c, 6 参照).

\section{4. 実験}

本 EEICO 分光装置の性能評価は, 高エネルギー加速器研 究機構内放射光施設 Photon Factory (PF) の軟 X 線ビーム ライン BL-1C とコインシデンス分光専用超高真空槽（到達 圧力： $1.5 \times 10^{-8} \mathrm{~Pa}$ ) を用いて行った. 放射光は, 試料表面 法線方向 $84^{\circ}$ から入射し, 試料表面上でのスポットサイズは $0.1 \mathrm{~mm} \times 4 \mathrm{~mm}$ (縦 $\times$ 横), 励起エネルギー $130 \mathrm{eV}$ における 放射光のエネルギー分解能 $E / \Delta E$ は〜 5000であった.

性能評価に用いた $\mathrm{Si}(001)-2 \times 1$ 清浄表面打よび $\mathrm{Si}(111)-$ $7 \times 7$ 清浄表面は，(1)シリコン $(\mathrm{Si})$ ウェハー (n-type, 0.02 $\Omega \cdot \mathrm{cm}$, ニラコ, 厚さ $0.5 \mathrm{~mm}$ ) から切り出した短冊状の $\mathrm{Si}$ 片を，自作の試料マニピュレーター28)の先端に取付け，(2) $<5.0 \times 10^{-7} \mathrm{~Pa}$ の超高真空下で, $\mathrm{Si}$ を $1100^{\circ} \mathrm{C}$ をで通電加 熱することで $\mathrm{Si}$ 酸化膜を取除き，(3)室温までゆっくりと冷 却する，といった手順で作製した. $\mathrm{Si}(001)-2 \times 1$ および $\mathrm{Si}$ (111) $-7 \times 7$ の表面再構成は, 低速電子線回折（Low-energy electron diffraction, LEED) パターンで確認した. 4 時間程 度のコインシデンス測定後も LEED パターンは変化しなか った。

EEICO 分光装置の性能は, $\mathrm{Si}(001)-2 \times 1$ および $\mathrm{Si}$ (111) $-7 \times 7$ 清浄表面の $\mathrm{Si} 2 p$ 光電子スペクトル $(\mathrm{PES})$ 測 定抢よび， $\mathrm{Si}(001)-2 \times 1$ 清浄表面の表面サイトを選別した $\mathrm{Si}-L_{23} V V-\mathrm{Si}-2 p \mathrm{APECS}$ 測定を行うことで評価した。ま た, 本 EEICO 装置が PEPICO 分光, AEPICO 分光測定に おいても従来以上の性能を発揮することは, 凝縮有機珪素分 子 $\mathrm{SiF}_{3} \mathrm{CD}_{2} \mathrm{CH}_{2} \mathrm{Si}\left(\mathrm{CH}_{3}\right)_{3}(\mathrm{FSMSE})$ の実験を行なうことで 確認しているが，別に報告する予定である ${ }^{29)}$.

ここで, EEICO 分光装置による $\mathrm{Si}(001)-2 \times 1$ 清浄表面 の $\mathrm{Si} L_{23} V V$ オージェ電子-Si $2 p$ 内殼光電子コインシデンス スペクトル $\left(\mathrm{Si}-L_{23} V V-\mathrm{Si}-2 p \mathrm{APECS}\right)$ の測定方法につい て簡潔に記す. 放射光を照射された $\mathrm{Si}(001)-2 \times 1$ から放出 された Si $2 p$ 内殼光電子は, DP-CMA によって分光され, MCPs でパルス信号として検出されたのち, マルチチャン ネルスケーラー(MCS, Laboratory equipments, LN-6500R, 分解能 $1 \mathrm{~ns}$ ) のトリガーシグナルとして入力される（Fig. 3 参照)。一方, Si $L_{23} V V$ オージェ電子は, ASMA によって 分光され，MCPs でパルス信号として検出されたのち，100 ns の遅延回路（delay）を介してMCS に入力される（Fig. 3 参照)。この計測システムで一定時間データを積算すると,

Fig. 2のような飛行時間（TOF）スペクトルを得ることが できる.トリガー光電子と同時に放出されたオージェ電子の 
シグナル（真のコインシデンスシグナル）は，トリガー光電 子の検出時間を時刻 $0 \mathrm{~ns}$ とすると，

（オージェ電子の ASMA 内での飛行時間）

+ （遅延時間，今回の測定では $100 \mathrm{ns）}$

- (光電子の DP-CMA 内での飛行時間)

の位置に現れる. 運動エネルギー $88 \mathrm{eV}$ の $\mathrm{Si} L_{23} V V$ オージ エ電子が放出されてから ASMAの MCPs で検出されるまで の飛行時間は33〜 $45 \mathrm{ns,}$ 運動エネルギー $26.6 \mathrm{eV}$ の Si $2 p$ 光 電子が放出されてから DP-CMAの MCPs で検出されるま での飛行時間は48～56 ns である. 飛行時間に幅があるのは Fig. 3 に示すように飛行距離が放出電子の極角に依存するた めである. 実際, 測定された APECS ピークの幅は (7)式で 完全に説明できる. 一方, トリガー光電子と無関係の過程で 放出されたオージェ電子は (7) 以外の飛行時間領域にランダ ムに現れ，バックグラウンドを形成する (Fig. 2 参照). ま た, コインシデンス分光でしばしば問題になるクロストーク シグナル*8は, 遅延時間の久に依存し幅も持たないため, 真 のコインシデンスピークとは明瞭に識別できる. 本 EEICO 装置では各シグナル線の距離を十分離すなどの対策を取って いるため, クロストークシグナルは無視できる.

DP-CMA に印加する電圧を Si $2 p$ 内殼光電子に固定し, ASMA に印加する電圧を $\mathrm{Si} L_{23} V V$ オージェ電子スペクト ル領域で掃引することによって得られた一連の飛行時間 (TOF) スペクトルを Fig. 7 に示す. APECS TOF スペク トル中のコインシデンスピークは, オージェ電子の運動エネ ルギー $(A e K E)$ が大きくなるに従って, 飛行時間が小さく なる方向にシフトしている．これは $A e K E$ が大きくなるほ どオージェ電子の飛行時間が小さくなるからである. APECS TOF スペクトルのコインシデンスピークの積分值 をAeKEの関数としてプロットすると $\mathrm{Si}-L_{23} V V-\mathrm{Si}-2 p$ APECS が得られる. 一連の APECS 測定に拈いては, 光電 子シグナル，オージェ電子シグナルも同時に測定している. このオージェ電子シグナルを用いると APECS とまったく同 じ条件で測定したオージェ電子スペクトルを得ることができ る. APECS 分野ではこのスペクトルをシングルスオージェ 電子スペクトル (singles AES) と呼んでいる. シングルス $\operatorname{AES}$ が通常のオージェ電子スペクトルに対応するのに対し, APECS はトリガー光電子に対応する AES を選択的に測定 する。 また，オージェ電子シグナルを MCSのトリガーと し, 光電子シグナルを MCS 入力すれば, 特定オージェ電子 と同時に放出された光電子のみを選択的に測定できる.この コインシデンススペクトルは APECS と区別して Photoelectron Auger-electron coincidence spectrum（PEACS）と呼ば れることがある。

\section{5. 性 能 評 価}

\section{$5.1 \mathrm{Si}(001)-2 \times 1$ および $\mathrm{Si}(111)-7 \times 7$ 清浄表面の $\mathrm{Si}$ $2 p$ 内殼光電子スペクトル測定}

ASMA および DP-CMAを用いて測定した室温の $\mathrm{Si}$

*8一方の分析器からのシグナルが, 容量結合や誘導結合によっ て, もう一方の分析器のシグナルにも出力されることに由来す るシグナルをクロストークと呼ぶ.
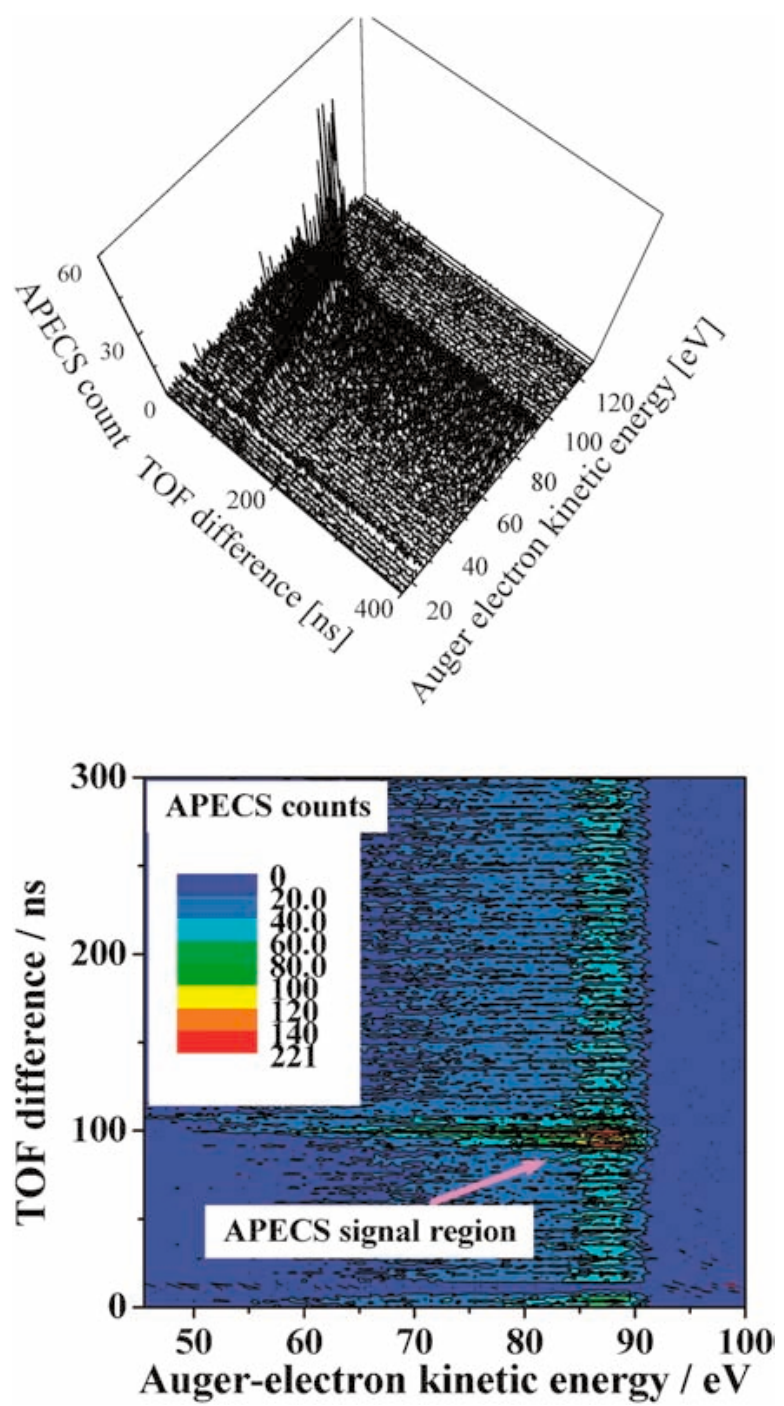

Fig. $7 \mathrm{Si}-L_{23} V V-\mathrm{Si}-2 p$ APECS TOF spectra of $\mathrm{Si}(001)-2 \times$ 1 and its contour map. The zero point of the TOF difference is shifted by $100-n$ s delay.

(001) $-2 \times 1$ 清浄表面の Si $2 p$ PES と Voigt 関数によるカー ブフィッティングの結果を Figs. 8a, 8b に示す. Si(001)-2 $\times 1$ のバルク Si $2 p$ 準位を基準とした表面 $\mathrm{Si} 2 p$ 準位の相対 的な結合エネルギーは, 表面の Si 2 量体（ダイマー）のア ップアトム, 第 3 層目 $\mathrm{Si}$, ダイマーのダウンアトム, およ び第 2 層目 $\mathrm{Si}$ の順に $0.5,0.23,-0.062$ ，および $-0.225 \mathrm{eV}$ であった。これらの值は, 従来の高分解能 Si $2 p \mathrm{PES}$ の結 果と一致している30). また, ASMA および DP-CMAを用 いて測定した室温における $\mathrm{Si}(111)-7 \times 7$ 清浄表面の $\mathrm{Si} 2 p$ PES とカーブフィッティングの結果を Figs. 8c, 8d に示す. $\mathrm{Si}(111)-7 \times 7$ のバルク Si $2 p$ 準位を基準とした Si $2 p$ 表面内 殼隼位の相対的なケミカルシフトは, S1：アドアトムに結 合した Si 原子レストアトム, S2：レストアトム, S3：アド アトム, S4 : ダイマー, および S5：未帰属のピークの順に - 0.247, 0.6, - 0.53, - 0.1, 抽び $-0.9 \mathrm{eV}$ であった。こ れらの值は, 液体窒素温度の $\mathrm{Si}(111)-7 \times 7$ 清浄表面の高分 解能 Si $2 p$ 内殼光電子スペクトルの結果と非常に近い值であ る31). 以上の全てのフィッティングに抢いて, ガウス幅は < $0.48 \mathrm{eV}$, ローレンツ幅は $0.08 \mathrm{eV}, 2 p_{1 / 2}$ と $2 p_{3 / 2}$ の間の 
Sample : Si(001)-2 $\times 1$

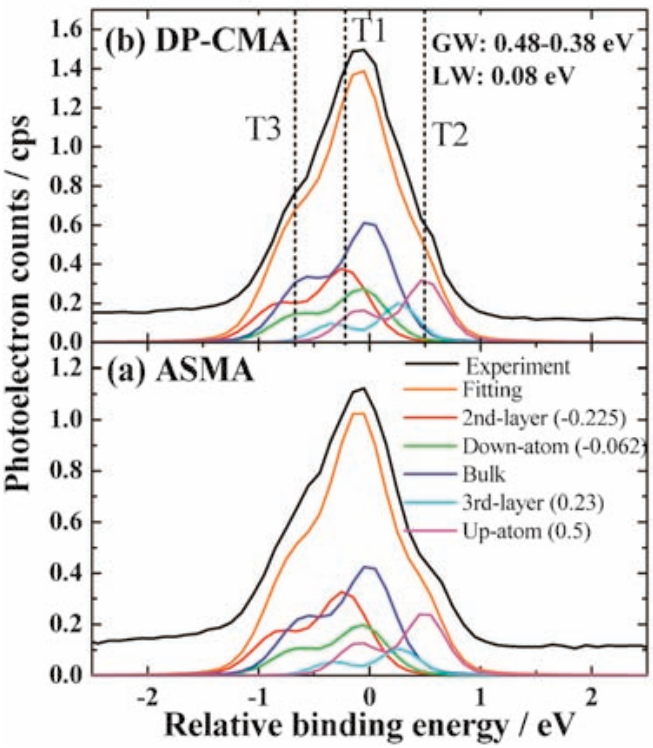

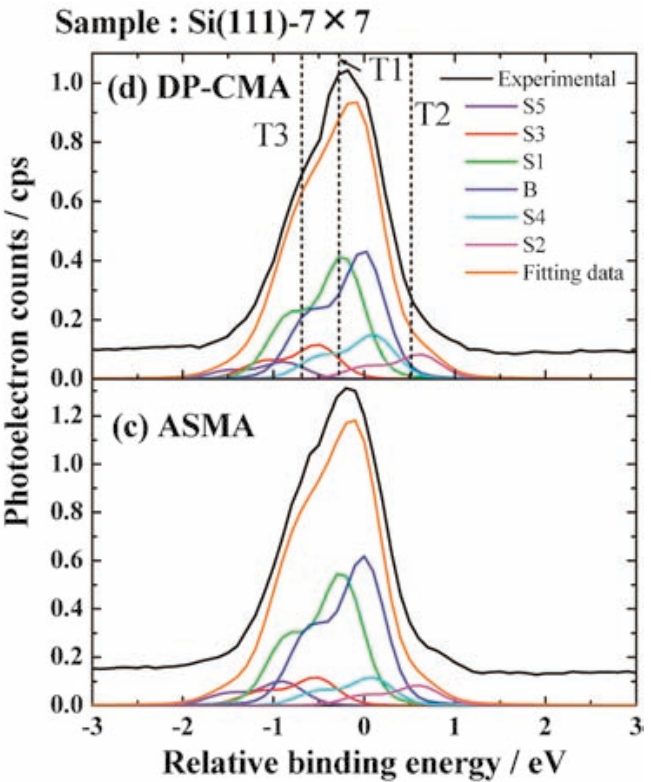

Fig. 8 Si $2 p$ core-level photoelectron spectra of $\operatorname{Si}(001)-2 \times 1$ and $\operatorname{Si}(111)-7 \times 7$ measured with the ASMA and the DP-CMA using synchrotron radiation at $130 \mathrm{eV}$. Fitting curves are also shown.

スピンー軌道分裂は $0.6 \mathrm{eV}$, 強度比 $\left(2 p_{1 / 2} / 2 p_{3 / 2}\right)$ は 0.5 とし た.フィッティングで得られたガウス幅から見積もった ASMA 抢よび DP-CMAのE/ $\Delta E$ は, 運動エネルギー $(K E)$ 領域 $20-30 \mathrm{eV}$ の範囲で両方とも〜 55であった。特に, DP-CMA の $E / \Delta E$ は, 先に報告した EEICO 分光器のシン グルパス CMA の $E / \Delta E(\sim 20)^{4)}$ から大きく改善されてい る.

\section{$5.2 \mathrm{Si}(001) 2 \times 1$ 清浄表面の表面 $\mathrm{Si}$ サイトの $\mathrm{Si} L_{23} V V$ オージェ電子-Si $2 p$ 光電子コインシデンススペクト ル}

本 EEICO 装置の性能を評価するために, $\mathrm{Si}(001)-2 \times 1$ 清浄表面の表面 $\mathrm{Si}$ サイトの $\mathrm{Si}-L_{23} V V-\mathrm{Si}-2 p \mathrm{APECS}$ 測定を 行なった. APECS シグナルの検出深さ $\left(E D_{\mathrm{APECS}}\right)$ は,

$$
\begin{aligned}
& \frac{1}{E D_{\mathrm{APECS}}}=\frac{1}{\mu_{\mathrm{PES}}}+\frac{1}{\mu_{\mathrm{AES}}}, \\
& \mu_{\mathrm{PES}}=\lambda_{\mathrm{PES}} \cos \theta_{\mathrm{PES}}, \\
& \mu_{\mathrm{AES}}=\lambda_{\mathrm{AES}} \cos \theta_{\mathrm{AES}}
\end{aligned}
$$

で与えられる5).ここで, $\lambda_{\mathrm{PES}}$ は光電子の非弾性平均自由行 程 (Inelastic Mean Free Path, IMFP)， $\lambda_{\mathrm{AES}}$ はオージェ電子 の IMFP， $\theta_{\mathrm{PES}}$ は表面法線方向からの光電子の放出角度, $\theta_{\mathrm{AES}}$ は表面法線方向からのオージェ電子の放出角度であ る. 今回の測定では, 光電子の運動エネルギーは〜 $26 \mathrm{eV}$ で あるから $\lambda_{\text {PES }}$ の実験值は〜 $3.3 \AA^{32}, 85 \mathrm{eV}$ のオージェ電子 の $\lambda_{\mathrm{AES}}$ は, 田沼らによって考案された TPP-2 式33)を用い ると〜 $4.9 \AA$ である。 また今回の測定では, $\theta_{\mathrm{PES}}$ は $37.5^{\circ} \pm$ $4^{\circ}, \theta_{\mathrm{AES}}$ は $59.5^{\circ} \pm 11.5^{\circ}$ であることから $E D_{\mathrm{APECS}}$ は $1.2 \AA$ となる。このため, 本 EEICO 装置による APECS は従来の 光電子分光, オージェ電子分光よりもはるかに表面敏感であ り, 表面 $\mathrm{Si}$ サイトの $\mathrm{Si}-L_{23} V V-\mathrm{Si}-2 p$ APECS 測定, $\mathrm{Si}-2 p-$ $\mathrm{Si}-L_{23} V V$ PEACS に適している.

Fig. 9 の赤丸と実線は, Fig. $8 \mathrm{~b}$ の T1 の $K E$ を持つ $\mathrm{Si} 2 p$ 光電子シグナル（主に第 2 層目の $\mathrm{Si}$ ）をトリガーとして測

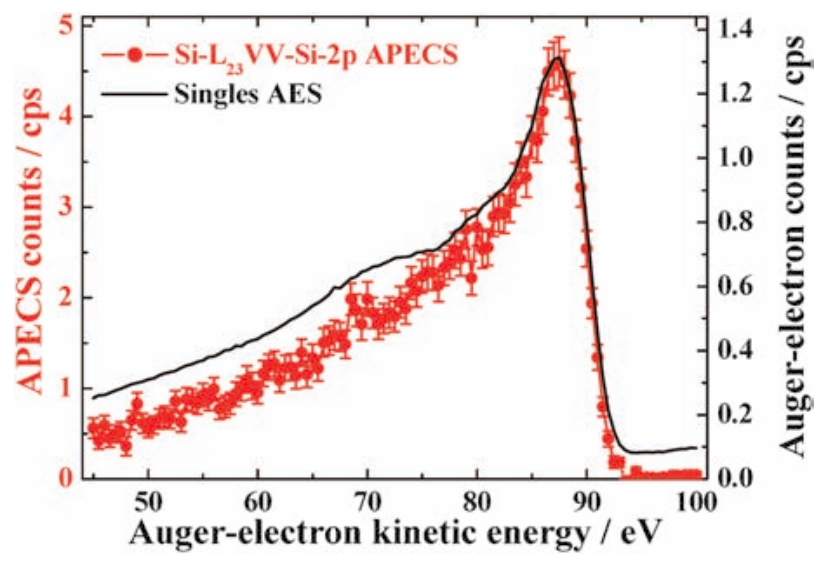

Fig. 9 The filled-circles and the solid line represent $\mathrm{Si}-L_{23}$ $V V-\mathrm{Si}-2 p$ APECS of $\mathrm{Si}(001)-2(1$ at $h v=130 \mathrm{eV}$. The solidline represents singles AES. The accumulated time at each datum was $300 \mathrm{~s}$.

定した $\mathrm{Si}(001)-2 \times 1$ 清浄表面の $\mathrm{Si}-L_{23} V V-\mathrm{Si}-2 p$ APECS である、また，黒の実線はシングルス AESである。シング ルス AES と比較すると $\mathrm{Si}-L_{23} V V-\mathrm{Si}-2 p$ APECS は,

1) $\mathrm{Si} L_{23} V V \mathrm{AES}$ のバックグラウンドを形成する 2 次電 子がほとんど現れない（特に，KE>93 eV, $K E<65 \mathrm{eV}$ のエネルギー領域で顕著),

2) Si $L_{23} V V$ AES ピークの線幅が細くなっている,

3) $K E=65-75 \mathrm{eV}$ 領域のプラズモン損失ピークの強度が 弱くなっている,

などの特徵が明瞭に現れている.これらの結果は以下のよう に説明できる。

1） 2 次電子はトリガーシグナルの $\mathrm{Si} 2 p$ 光電子と相関が ないため APECS には現れない。

2）通常のオージェ電子スペクトルはすべての光電子に 対応するのに対し, $\mathrm{Si}-L_{23} V V-\mathrm{Si}-2 p$ APECS は特定の 


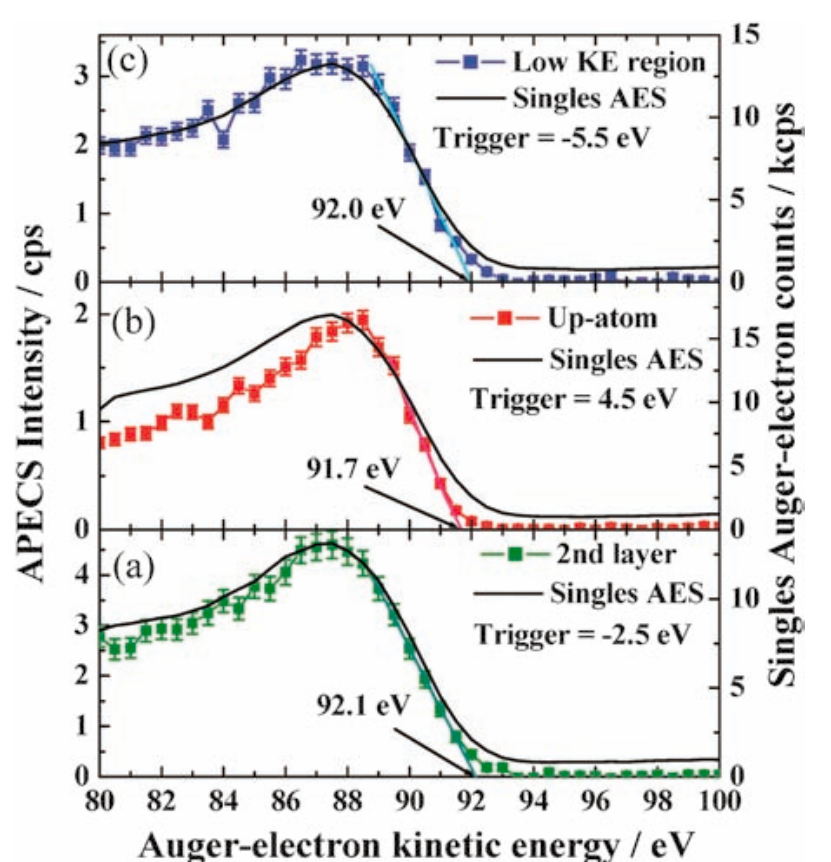

Fig. $10 \mathrm{Si}-L_{23} V V-\mathrm{Si}-2 p$ APECS, where the $\mathrm{Si} L_{23} V V$ AES were measured in coincidence with the Si $2 p$ photoelectron of (a) the 2nd layer component, (b) dimmer-up-atom component, and (c) the low KE component of $\mathrm{Si}(001)-2 \times 1$. The solid lines represent singles AES. The accumulation time per datum was (a) $300 \mathrm{~s}$, (b) $1200 \mathrm{~s}$, and (c) $600 \mathrm{~s}$.

光電子放出に対応するオージェ電子のみを測定するの で，ピーク幅が狭くなる ${ }^{9)}$.

3）表面最上層から放出されたオージェ電子がプラズモ ンを励起する確率は低いので APECS ではプラズモン 損失ピークも抑制される ${ }^{34}$.

また, APECS シグナル計数率は最大で $4.5 \mathrm{cps}$ 程度で, Fig. 9 の APECS 測定時間は 9 時間15分程度であった。この 条件であれば清浄表面を十分維持できるので, 測定時間とし て妥当である.

Fig. 8b 中の T1 : 表面第 2 層目, T2 : 2 量体のアップア トム, $\mathrm{T} 3$ : 光電子ピークの低運動エネルギー成分をトリ ガーシグナルとして測定した $\mathrm{Si}-L_{23} V V-\mathrm{Si}-2 p$ APECS を Fig. 10に示す. 2 量体のアップアトムの Si $2 p$ 内殼光電子を 主成分とするシグナルに対応する $\mathrm{Si}-L_{23} V V-\mathrm{Si}-2 p$ APECS (Fig. 10b) は, Figs. 10a, 10c と比較して,

1）低運動エネルギー側での強度が減少している,

2) メインピーク位置が高 $A e K E$ 側にシフトしている,

3） カットオフ位置が低 $A e K E$ 側にシフトしている, 等の特徵が明瞭に現れている. 詳細は省くが，これらの結果 はトリガーシグナルの主成分である Si ダイマーアップアト ムサイトの $\mathrm{Si} L_{23} V V \mathrm{AES}$ を反映していることで説明でき る.このAPECSを解析すれば, $\operatorname{Si}(001)-2 \times 1$ 清浄表面の $\mathrm{Si}$ ダイマーアップアトムサイトの局所価電子状態について 考察することが可能である。これらの点は, $\mathrm{Si}(111)-7 \times 7$ 清浄表面の APECS 測定結果と考察とともに別の論文にまと める予定である.

\section{6. ま ぬ}

我々は，ASMA および DP-CMA，TOF-MS，磁気シー ルド, XYZ ステージ, 傾き調整機構, ICF203 から構成され る新しい EEICO 分光装置を開発した. Si (001) $-2 \times 1$ 清浄 表面および $\mathrm{Si}(111)-7 \times 7$ 清浄表面から見積もった ASMA および DP-CMA のエネルギー分解能 $(E / \Delta E)$ は， $K E=$ 20-30 eV の範囲で〜 55であった. 本装置を用いて $\mathrm{Si}(001)-$ $2 \times 1$ 清浄表面の $\mathrm{Si}$ 表面特定サイトの $\mathrm{Si}-L_{23} V V-\mathrm{Si}-2 p$ APECS を測定できた. また, APECS 計数率も $4.5 \mathrm{cps}$ まで 高めることができ, APECS測定時間を短縮した。本 EEICO 装置の開発により, 微小な表面ケミカルシフトの違 いを利用して特定表面サイトの局所電子状態研究を行なうこ とが可能になった.

EEICO 分光器製作を支援してくださった岡田直之氏，小 山田健氏（群馬大学教育学部大学院教育学研究科を 2007 年 3 月に卒業), EEICO 分光器部品を製作してくださった小林芳 治氏（高エネルギー加速器研究機構機械工学センター）に感 謝します. また, 福島整氏, 吉川英樹氏（独物質・材料研究 機構）には2.2節（APECS 装置開発の歴史）執筆あたりご 教示いただきました. 本研究は科学技術振興機構戦略的創造 研究推進事業個人型研究 (研究領域「構造機能と計測分析」) および平成19-20年度高エネルギー加速器研究機構共同開発 研究の助成を受けをした. APECS 測定は, 高エネルギー加 速器研究機構放射光共同利用実験課題2006S2-002のもとに 行われました。

\section{〔文献〕}

1) K. Mase, E. Kobayashi and K. Isari: in Correlation Spectroscopy of Surfaces, Thin Films and Nanostructures, Edited by J. Berakdar and J. Kirschner (WILEY-VCH Verlag GmbH \& Co. KGaA, Weinheim, 2004.) Chap. 16, pp. 206-225.

2) E. Kobayashi, K. Mase, A. Nambu, J. Seo, S. Tanaka, T. Kakiuchi, K. K. Okudaira, S. Nagaoka and M. Tanaka: J. Phys.: Condens. Matter, 18 (2006) S1389.

3) K. Mase, M. Nagasono, S. Tanaka, T. Sekitani and S. Nagaoka: Fizika Nizkikh Temperatur, 29 (2003) 321.

4) T. Kakiuchi, E. Kobayashi, N. Okada, K. Oyamada, M. Okusawa, K. K. Okudaira and K. Mase: J. Electron Spectrosc. Relat. Phenom., 161 (2007) 164.

5) G. A. Sawatzky: in Auger Electron Spectroscopy, edited by C. L. Briant and R. P. Messmer (Academic, 1988) chapter 5.

6) K. Siegbahn, N. Kholine and G. Golikov: Nucl. Instrum. Meth. Phys. Res. A, 384 (1997) 563.

7) H. W. Haak, G. A. Sawatzky and T. D. Thomas: Phys. Rev. Lett., 41 (1978) 1825.

8) H. W. Haak, G. A. Sawatzky, L. Ungier, K. Gimzewski and T. D. Thomas: Rev. Sci. Instrum., 55 (1984) 696.

9) E. Jensen, R. A. Bartynski, S. L. Hulbert, E. D. Johnson and R. Garrett: Phys. Rev. Lett., 62 (1989) 71.

10) S. Thurgate, B. Todd, B. Lohmann and A. Stelbovics: Rev. Sci. Instrum.: 61 (1990) 3733.

11) R. Gotter, A. Ruocco, A. Morgante, D. Cvetko, L. Floreano, F. Tommasini and G. Stefani: Nuclear Instrum. Meth. Phys. Res. A, 467-468 (2001) 1468.

12) M. Hattass, T. Jalowy, A. Czasch, Th. Weber, T. Jahnke, S. Schössler, L. Ph. Schmidt, O. Jagutzki, R. Dörner and H. Schimidt-Böcking: Rev. Sci. Instrum., 75 (2004) 2373.

13) J. Krischner, G. Kerhervé and C. Winkler: Rev. Sci. Instrum., 
79 (2008) 073302.

14）釜田重徳, 系井勇人, 奥沢 誠, 菅原英直: 群馬大学教育学 部紀要自然科学編, 47 (1999) 21.

15）系井勇人, 釜田重徳, 高野勝昌, 奥沢 誠: 群馬大学教育学 部紀要自然科学編, 48 (2000) 61.

16）小暮 匠, 奥沢 誠: 群馬大学教育学部紀要自然科学編, 53 (2005) 51.

17) H. Yoshikawa, Y. Kita, K. Watanabe, A. Tanaka, M. Kimura, A. Nisawa, V. A. Mihai, M. Kitamura, N. Yagi, M. Okui, M. Taguchi, R. Oiwa and S. Fukushima: J. Surf. Anal., 9 (2002) 374.

18) Z. Zhang, Z. Ding, T. Koshikawa, T. Iyasu, R. Shimizu, H. Yoshikawa, S. Fukushima and A. Tanaka: Surf. Sci., 592 (2005) 18.

19) K. Mase, E. Kobayashi, M. Mori, Y. Kobayashi, S. Terashima, K. K. Okudaira and N. Ueno: Shinku, 47 (2004) 334.

20) E. Kobayashi, J. Seo, A. Nambu and K. Mase: Surf. Sci., 601 (2007) 3589.

21) M. L. Knotek and J. W. Rabalais: in Desorption Induced by Electronic Transitions, DIET-II, Vol. 4 of Springer Series in Surface Sciences, eds. W. Brenig and D. Menzel (Springer, Berlin, 1985), p. 77.

22) K. Mase, M. Nagasono and T. Urisu: Bull. Chem. Soc. Jpn., 69 (1996) 1829.

23) K. Mase, M. Nagasono, S. Tanaka, M. Kamada, T. Urisu and
Y. Murata: Rev. Sci. Instum., 68 (1997) 1703.

24) K. Mase, S. Tanaka, S. Nagaoka and T. Urisu: Surf. Sci., 451 (2000) 143.

25) K. Isari, E. Kobayashi, K. Mase and K. Tanaka: Surf. Sci., 528 (2003) 261.

26) T. Kakiuchi, E. Kobayashi, K. K. Okudaira, N. Fujita, M. Tanaka and K. Mase: Anal. Sci., 24 (2008) 8.

27） MCP アッセンブリ技術資料, 浜松ホトニクス株式会社(2002).

28) T. Kakiuchi and K. Mase: J. Vac. Soc. Jpn., 51 (2008) 44.

29) K. Mase, E. Kobayashi, A. Nambu, T. Kakiuchi, S. Nagaoka, O. Takahashi, K. Tabayashi, M. Mitani, J. Ohshita, S. Hashimoto and M. Tanaka: In preparation.

30) E. Landemark, C. J. Karlsson, Y.-C. Chao and R. I. G. Uhrberg: Phys. Rev. Lett., 69 (1992) 1588.

31) C. J. Karlsson, E. Landemark, Y.-C. Chao and R. I. G. Uhrberg: Phys. Rev. B, 50 (1994) R5767.

32) F. J. Himpsel, F. R. McFeely, A. Taleb-Ibrahimi, J. A. Yarmoff and G. Hollinger: Phys. Rev. B, 38 (1988) 6084.

33) S. Tanuma, C. J. Powell and D. R. Penn: Surf. Interface Anal., 17 (1991) 911.

34) W. S. M. Werner, W. Smekal, H. Störi, H. Winter, G. Stefani, A. Ruocco, F. Offi, R. Gotter, A. Morgante and F. Tommasini: Phys. Rev. Lett., 94 (2005) 038302. 